\title{
Mulching Technology and Giving NPK Fertilizer to Increase The Growth and Yield of Shallots
}

\author{
Luh Kartini $^{1^{*}}$, Made Sri Yuliartini ${ }^{2}$ \\ Universitas Warmadewa, Denpasar-Bali, Indoensia \\ \{luhkartini59@gmail.com¹,yuliartinisri@yahoo.co.id²
}

\begin{abstract}
Shallots plants are one of the leading national commodities in addition to chilies and potatoes. The government must re-evaluate to intensify and encourage farmers to re-plant crops that have been a daily necessity in the community. Although it cannot be denied, that the need for shallots in Indonesia has been an important note in advancing agricultural production. This study aims to obtain the most appropriate mulching technology and NPK fertilizer dosage for improving the physical condition and soil fertility and the availability of nutrients to obtain maximum growth and yield of shallots. The method used in achieving the goal is the experimental method in the field using a factorial randomized block design (RBD) with three levels of mulch types and four levels of NPK fertilizer doses. The highest oven dry weight of tubers per clump was obtained in the interaction between types of rice husk mulch with a dose of NPK fertilizer $250 \mathrm{~kg} \mathrm{ha}^{-1}\left(\mathrm{MsP}_{3}\right)$ of $3.53 \mathrm{~g}$ which was very significantly different with the lowest yield of $2.20 \mathrm{~g}$ obtained in the interaction between species. rice husk mulch with a dose of NPK fertilizer $150 \mathrm{~kg} \mathrm{ha}^{-1}\left(\mathrm{MsP}_{1}\right)$.
\end{abstract}

Keywords: Shallots; Mulch; NPK Fertilizer

\section{Introduction}

Shallots are one of the leading national commodities in addition to chilies and potatoes. The government must re-evaluate to intensify and encourage farmers to re-plant crops that have been a daily necessity in the community. Although it cannot be denied, that the need for onions in Indonesia has been an important note in advancing agricultural production, because Indonesia is known for its fertile land and the government continues to focus on encouraging and advancing the agricultural sector by implementing five farming practices.

Increasing the intensity of shallot cultivation in various districts, requires more research on appropriate technology combined with local resources that are easy to apply according to farmers' abilities and have a real impact on increasing income. Considering that the vast area of land resources and increasing skills and experience of farmers can be developed on a small and medium scale, the availability of land as a growing medium can still be pursued, using relatively simple management, to increase the income and welfare of small business operators.

Mulch technology is an effort to improve the physical condition of the soil. Mulch is divided into two, namely organic and inorganic mulch. Organic mulch is plant residue such as rice husks and straw, while inorganic mulch includes artificial materials such as silver black plastic [1]. Technically, the use of mulch can provide benefits, including saving water use by reducing the rate of evaporation from the soil surface, reducing soil temperature fluctuations, 
thereby benefiting the growth of shallot plants and soil micro organisms, reducing the rate of soil erosion, both due to raindrops and can inhibits weed growth rate [2].

On the other hand, fertilization is an effort to provide nutrients needed by plants and plays an important role in increasing the yield of shallot plants, one of which is by using NPK Mutiara 16:16:16 [3]. This fertilizer contains elements of $\mathrm{N}, \mathrm{P}_{2} \mathrm{O}_{5}, \mathrm{~K}_{2} \mathrm{O}, \mathrm{MgO}$ and $\mathrm{CaO}$, besides that, NPK is easily soluble, so it can be absorbed directly by plants [4]. The results of the research on NPK pearl fertilizer with a dose of $200 \mathrm{Kg}_{\text {ha }}$ gave the best results on shallot plants [5].

Through proper mulching technology and the use of NPK Fertilizer in the right dosage, it can increase the growth and yield of onion plants

\section{Method}

The research method used a factorial randomized block design consisting of two factors, namely the first factor was the type of mulch $(\mathrm{M})$ consisting of rice straw mulch $(\mathrm{Mj})$, rice husk mulch (Ms) and black silver plastic mulch (Mp). While the second factor is NPK pearl (P) fertilizer which consists of $0 \mathrm{~kg} \mathrm{ha}^{-1}\left(\mathrm{P}_{0}\right), 150 \mathrm{~kg} \mathrm{ha}^{-1}\left(\mathrm{P}_{1}\right), 200 \mathrm{~kg} \mathrm{ha}^{-1}\left(\mathrm{P}_{2}\right)$ and $250 \mathrm{~kg} \mathrm{ha}^{-1}$ $\left(\mathrm{P}_{3}\right)$. Thus there are 12 treatment combinations, namely $\mathrm{MjP} \mathrm{P}_{0}, \mathrm{MjP}_{1}, \mathrm{MjP}_{2}, \mathrm{MjP}_{3}, \mathrm{MsP}_{0}, \mathrm{MsP}_{1}$, $\mathrm{MsP}_{2}, \mathrm{MsP}_{3}, \mathrm{MpP}_{0}, \mathrm{MpP}_{1}, \mathrm{MpP}_{2}$ and $\mathrm{MpP}_{3}$. This research was conducted in Sanding Village, Tampaksiring District, Gianyar Regency, the altitude is approximately $750 \mathrm{~m}$ above sea level and an average temperature of $23-29^{\circ} \mathrm{C}$ and was carried out from June to September 2020.

The implementation of the experiment included land preparation, namely the land to be processed and then cleaned and leveled, mapped, mulching technology on the soil surface, planting, giving NPK fertilizer treatment and plant maintenance. The research instrument was carried out on the variables of plant growth and development and harvest. The variables observed were plant height, number of leaves, number of tubers per clump, fresh weight and oven dry weight of tubers per clump, fresh weight and oven dry weight of stover per clump and tuber weight per ha- ${ }^{-1}$.

\section{Results and Discussion}

From the results of statistical analysis of all observed variables and the results of the significance of the type of mulch (M) and the dose of NPK fertilizer (P) and its interaction $(\mathrm{MxP})$ on the observed variables are presented in Table 1.

Table 1. The Significance of the Effect of Pulverizing Technology and NPK Fertilizer to Increase the Growth and Yield of Shallots.

\begin{tabular}{clccc}
\hline \multirow{2}{*}{ No. } & \multicolumn{1}{c}{ Variable } & \multicolumn{3}{c}{ Treatment } \\
\cline { 3 - 5 } & & $\begin{array}{c}\text { Types of Mulch } \\
(\mathbf{M})\end{array}$ & $\begin{array}{c}\text { NPK } \\
(\mathbf{P})\end{array}$ & $\begin{array}{c}\text { Interaction } \\
(\mathbf{M x P})\end{array}$ \\
\hline 1 & Plant height (cm) & $\mathrm{Ns}$ & $* *$ & $\mathrm{~ns}$ \\
2 & Number of leaves (strands) & $\mathrm{Ns}$ & $* *$ & $\mathrm{~ns}$ \\
3 & Number of tubers (tubers) & $\mathrm{Ns}$ & $\mathrm{ns}$ & $\mathrm{ns}$ \\
4 & Tubers fresh weight $(\mathrm{g})$ & $\mathrm{Ns}$ & $*$ & $\mathrm{~ns}$ \\
5 & Tubers oven dry weight $(\mathrm{g})$ & $\mathrm{Ns}$ & $* *$ & $* *$
\end{tabular}




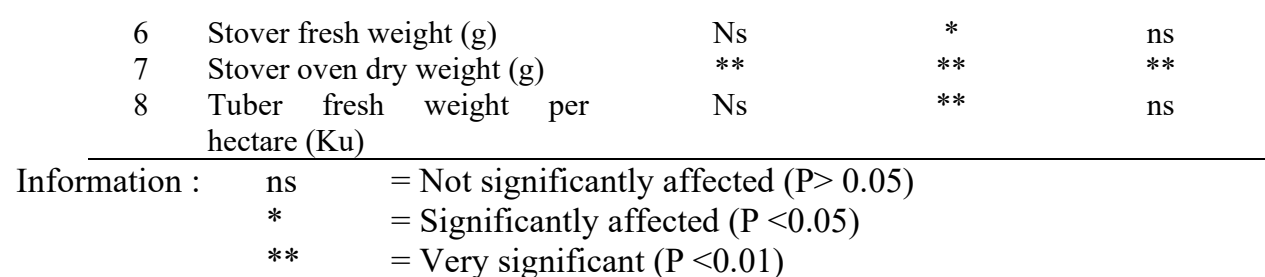

The interaction between the type of mulch and the NPK fertilizer dose (MxP) had no significant effect $(\mathrm{P} \geq 0.05)$ on most of the observed variables, except for the oven dry weight of tubers and the oven dry weight of stover, which had a very significant effect. $(\mathrm{P}<0.01)$. Type of mulch (M) had no significant effect on most of the observed variables, except for the stover oven dry weight variable which had a very significant effect $(\mathrm{P}<0.01)$. NPK fertilizer (P) had a significant to very significant effect on most of the observed variables, except for the number of tubers that had no significant effect $(\mathrm{P}>0.05)$. The average of all variables observed in the type of musa (M) treatment can be seen in Table 2. The fresh weight of tubers per hill was obtained in plastic mulch $(\mathrm{Mp})$ and the lowest was in husk mulch (Ms), which were $63.05 \mathrm{~g}$ and $9.22 \mathrm{~g}$, respectively.

Table 2. Average of all observed variables in the type of mulch treatment (M)

\begin{tabular}{lrrrc}
\hline \multirow{2}{*}{ Variable } & \multicolumn{4}{c}{ Mulch Type (M) } \\
\cline { 2 - 5 } & $\begin{array}{r}\text { Mulch } \\
\text { Straw }\end{array}$ & $\begin{array}{c}\text { Mulch } \\
\text { Husk }\end{array}$ & $\begin{array}{c}\text { Mulch } \\
\text { Plastic }\end{array}$ & $\begin{array}{c}\text { BNT } \\
\text { 5\% }\end{array}$ \\
\hline Plant height (cm) & $35.53 \mathrm{a}$ & $37.97 \mathrm{a}$ & $40.78 \mathrm{a}$ & - \\
Number of leaves (strands) & $25.26 \mathrm{a}$ & $29.83 \mathrm{a}$ & $27.15 \mathrm{a}$ & - \\
Number of tubers (tubers) & $6.94 \mathrm{a}$ & $7.83 \mathrm{a}$ & $8.42 \mathrm{a}$ & - \\
Fresh weight of tubers $(\mathrm{g})$ & $60.05 \mathrm{a}$ & $55.81 \mathrm{a}$ & $63.06 \mathrm{a}$ & - \\
Stover fresh weight $(\mathrm{g})$ & $12.59 \mathrm{a}$ & $9.22 \mathrm{a}$ & $12.70 \mathrm{a}$ & - \\
Fresh weight of tubers ha ${ }^{-1}$ & $152.53 \mathrm{a}$ & $141.47 \mathrm{a}$ & $173.17 \mathrm{a}$ & - \\
$(\mathrm{Ku})$ & & & & \\
\hline
\end{tabular}

Information : The average value followed by the same letter in the same treatment showed no significant difference in the 5\% LSD test

The average of all variables observed in the fertilizer dose treatment can be seen in Table 3.The fresh weight of tubers per clump was obtained at the NPK fertilizer dose of $250 \mathrm{~kg} \mathrm{ha}^{-1}$ and the lowest was the NPK fertilizer dose of $0 \mathrm{~kg} \mathrm{ha}^{-1}$ (control), namely, respectively. $72.42 \mathrm{~g}$ and $45.08 \mathrm{~g}$.

Table 3. Average of all observed variables in NPK fertilizer treatment (P)

\begin{tabular}{|c|c|c|c|c|c|c|c|c|c|}
\hline \multirow[b]{2}{*}{ Variable } & \multicolumn{9}{|c|}{ NPK (P) } \\
\hline & \multicolumn{2}{|c|}{$0 \mathrm{~kg} \mathrm{ha}^{-1}$} & \multicolumn{2}{|c|}{$\underset{1}{150 \mathrm{~kg} \mathrm{ha}^{-}}$} & \multicolumn{2}{|c|}{$200 \mathrm{~kg} \mathrm{ha}^{-1}$} & \multicolumn{2}{|c|}{$250 \mathrm{~kg} \mathrm{ha}^{-1}$} & LSD \\
\hline Plant height $(\mathrm{cm})$ & 30.54 & $\mathrm{c}$ & 36.99 & $\mathrm{~b}$ & 40.61 & $\mathrm{ab}$ & 44.33 & $\mathrm{a}$ & 4.32 \\
\hline Number of leaves (strands) & 20.72 & $\mathrm{~b}$ & 28.10 & $\mathrm{a}$ & 28.36 & $\mathrm{a}$ & 32.47 & $\mathrm{a}$ & 5.63 \\
\hline Number of tubers (tubers) & 7.43 & a & 7.31 & a & 7.78 & $\mathrm{a}$ & 8.42 & $\mathrm{a}$ & - \\
\hline Fresh weight of tubers $(\mathrm{g})$ & 45.08 & $\mathrm{~b}$ & 59.44 & $\mathrm{a}$ & 61.61 & $\mathrm{a}$ & 72.42 & $\mathrm{a}$ & 13.24 \\
\hline Stover fresh weight $(\mathrm{g})$ & 8.39 & $\mathrm{~b}$ & 8.89 & $\mathrm{~b}$ & 14.85 & a & 13.90 & a & 4.47 \\
\hline Fresh weight of tubers $\mathrm{ha}^{-1}$ & 112.2 & $\mathrm{~b}$ & 149.1 & $\mathrm{~b}$ & 178.6 & $\mathrm{~b}$ & 182.92 & $\mathrm{a}$ & 35.06 \\
\hline$(\mathrm{Ku})$ & 0 & & 4 & & 2 & & & & \\
\hline
\end{tabular}


Information: The average value followed by the same letter in the same treatmentshowed no significan difference in the $5 \%$ LSD test

The interaction between the type of mulch and NPK fertilizer (M x P) had a very significant effect on the oven dry weight of tubers per hill (Table 4). The table shows that the highest oven dry weight of tubers per clump was obtained from the interaction between the type of husk mulch and the NPK fertilizer dose of $250 \mathrm{~kg} \mathrm{ha}^{-1}\left(\mathrm{MsP}_{3}\right)$ of $3.53 \mathrm{~g}$ which was very significantly different with the lowest yield of $2.20 \mathrm{~g}$ obtained. on the interaction between types of rice husk mulch with a dose of NPK fertilizer $150 \mathrm{~kg} \mathrm{ha}^{-1}\left(\mathrm{MsP}_{1}\right)$

Table 4. Average oven dry weight of tubers per hill (g) on the effect of interaction Types of mulch and NPK fertilizer (M x P )

\begin{tabular}{cccccccccc}
\hline & \multicolumn{10}{c}{ NPK Fertilizer (P) } \\
\cline { 2 - 10 } Treatmen & $\mathrm{P}_{0}$ & \multicolumn{1}{c}{$\mathrm{P}_{1}$} & $\mathrm{P}_{2}$ & & $\mathrm{P}_{3}$ & \\
\hline Mulch Type (M) & & & & & & & & \\
Mj & 3.23 & $\mathrm{~A}$ & 3.03 & $\mathrm{~A}$ & 3.23 & $\mathrm{~A}$ & 3.13 & $\mathrm{~A}$ \\
& $\mathrm{a}$ & & $\mathrm{a}$ & & $\mathrm{a}$ & & $\mathrm{b}$ & \\
$\mathrm{Mp}$ & 3.00 & $\mathrm{~B}$ & 3.23 & $\mathrm{AB}$ & 3.43 & $\mathrm{~A}$ & 3.23 & $\mathrm{AB}$ \\
& $\mathrm{a}$ & & $\mathrm{A}$ & & $\mathrm{a}$ & & $\mathrm{ab}$ & \\
$\mathrm{Ms}$ & 3.17 & $\mathrm{~A}$ & 2.20 & $\mathrm{C}$ & 3.40 & $\mathrm{AB}$ & 3.53 & $\mathrm{~A}$ \\
& $\mathrm{a}$ & & $\mathrm{B}$ & & $\mathrm{a}$ & & $\mathrm{a}$ & \\
\hline LSD 0.05 & 0.35 & & & & & & & \\
\hline
\end{tabular}

Information: Numbers followed by the same lowercase letter in the vertical direction and letter the same capital direction horizontally is not significantly different in the 5\% LSD test.

The interaction between the type of mulch and NPK fertilizer ( $\mathrm{M} \times \mathrm{P})$ had a very significant effect on the staged oven dry weight variable (Table 5). The table shows that the highest stover oven dry weight was obtained in the interaction between the type of husk mulch and the NPK fertilizer dose of $250 \mathrm{~kg} \mathrm{ha}^{-1}\left(\mathrm{MsP}_{3}\right)$ of $7.03 \mathrm{~g}$ which was very significantly different with the lowest yield of $0.80 \mathrm{~g}$ obtained in the interaction. between types of rice straw mulch with a dose of $200 \mathrm{~kg}$ of NPK fertilizer ha ${ }^{-1}\left(\mathrm{MjP}_{2}\right)$.

Table 5. Average Oven Dry Weight Rate per hill (g) on influence Interaction of Mulch Types and NPK Fertilizer (M x P)

\begin{tabular}{ccccccccc}
\hline \multirow{2}{*}{ Treatment } & \multicolumn{8}{c}{ NPK Fertilizer (P) } \\
\cline { 2 - 9 } & $\mathrm{P}_{0}$ & & $\mathrm{P}_{1}$ & $\mathrm{P}_{2}$ & $\mathrm{P}_{3}$ & \\
\hline Mulch Type (M) & & & & & & & & \\
$\mathrm{Mj}$ & 1.33 & $\mathrm{~B}$ & 1.97 & $\mathrm{~B}$ & 0.80 & $\mathrm{~B}$ & 4.47 & $\mathrm{~A}$ \\
& $\mathrm{a}$ & & $\mathrm{a}$ & & $\mathrm{A}$ & & $\mathrm{b}$ & \\
$\mathrm{Mp}$ & 1.00 & $\mathrm{~A}$ & 2.43 & $\mathrm{~A}$ & 1.90 & $\mathrm{~A}$ & 1.13 & $\mathrm{~A}$ \\
& $\mathrm{a}$ & & $\mathrm{a}$ & & $\mathrm{A}$ & & $\mathrm{c}$ & \\
$\mathrm{Ms}$ & 1.60 & $\mathrm{~B}$ & 1.50 & $\mathrm{~B}$ & 2.50 & $\mathrm{~B}$ & 7.03 & $\mathrm{~A}$ \\
& $\mathrm{a}$ & & $\mathrm{a}$ & & $\mathrm{A}$ & & $\mathrm{a}$ &
\end{tabular}




\begin{tabular}{ll}
\hline LSD 0.05 & 1.81 \\
\hline Information: & The numbers followed by the same lowercase letter in the vertical \\
direction and the same capital letters in the horizontal direction are not \\
significantly different in the test LSD $5 \%$.
\end{tabular}

The interaction between the type of mulch and NPK fertilizer (M x P) had a very significant effect on the oven dry weight of tubers per hill (Table 4). The table shows that the highest oven dry weight of tubers per clump was obtained in the interaction between the type of husk mulch and the NPK fertilizer dose of $250 \mathrm{~kg} \mathrm{ha}^{-1}\left(\mathrm{MsP}_{3}\right)$ of $3.53 \mathrm{~g}$ which was very significantly different with the lowest yield of $2.20 \mathrm{~g}$ obtained. on the interaction between types of rice husk mulch with a dose of NPK fertilizer $150 \mathrm{~kg} \mathrm{ha}^{-1}\left(\mathrm{MsP}_{1}\right)$. This shows that there is a more effective absorption of nutrients and greater photosynthate formation at the NPK fertilizer dose of $150 \mathrm{~kg} \mathrm{ha}^{-1}$. This condition causes the treatment to produce a better oven dry tuber weight than the other treatments. Phosphorus is one of the essential nutrients needed by plants for optimum growth and yield. Nutrients that have been absorbed by the roots, especially phosphorus $(\mathrm{P})$, contribute to the weight gain of plant tubers [6].

The element phosphorus is a growth stimulant for plant roots and is a raw material for growth and formation of a number of proteins and helps assimilation and respiration and even accelerates flowering, ripening of seeds and fruit. Phosphorus is also useful for plants to stimulate root growth, especially the roots of seeds and young plants [7].

Nitrogen is the main constituent of protein or as a basic ingredient for protein and the formation of chlorophyll. With the increase in chlorophyll, the photosynthetic activity will increase which later the resulting photosynthate will also increase, which will then be transferred to plant organs that are active in metabolic processes, so that the growth of the vegetative parts of the plant will be better and will further affect plant yields [8].

Tuber weight is related to the parameter of the number of leaves and the number of tubers per clump. The number of leaves will increase the photosynthesis process and produce a lot of photosynthate which is then translocated to storage organs such as tubers. The amount of photosynthate stored in the tuber will increase the tuber weight [9].

Plant growth will affect crop yield as indicated by the number of tubers per clump followed by maximum plant height and maximum number of leaves. This is because the availability of nutrients found in NPK fertilizers supports the nutrients in the soil. From the results of soil analysis, it shows that the availability of potassium in the natural soil is very low, so that the addition of potassium nutrients through NPK fertilizer in plants will affect the number of tubers to increase. The nutrient potassium plays a very important role in translocation and storage of assimilates and in increasing the number of tubers [10].

\section{Conclusion}

The interaction between the type of mulch and the dosage of NPK fertilizer (MxP) had a very significant effect on the oven dry weight of tubers per grass and the oven dry weight of stover.

The highest oven dry weight and stover oven dry weight were obtained in the interaction between husk mulch and NPK fertilizer $250 \mathrm{Kg} \mathrm{ha}^{-1}\left(\mathrm{MsP}_{3}\right)$, namely $3.53 \mathrm{~g}$ and $7.03 \mathrm{~g}$.

The type of mulch $(\mathrm{M})$ had a very significant effect on the stover oven dry weight variable and had no significant effect on other observed variables. 
NPK fertilizer (P) had a significant to very significant effect on most of the observed variables, except for the number of tubers that had no significant effect $(\mathrm{P}>0.05)$.

\section{Acknowledgments}

The author would like to thank the Chairman of the Yayasan Korpri Propinsi Bali, Rector of Warmadewa University, the Head of the Warmadewa University Research Institute, the Dean of the Faculty of Agriculture and colleagues who have provided all support in completing this research.

\section{References}

[1] Sembiring, A. P. (2013). Pemanfaatan Mulsa Plastik Hitam Perak (MPHP) dalam Budidaya Cabai(Capsicum annum L).http://www.scribd.com/doc/82000378/Pemanfaatan-Mulsa-PlastikHitam-PerakMPHP-Dalam-Budi daya-CabaiCapsicum-Annum-L. Diakses pada tanggal 19 Agustus 2020.

[2] Litbang, (2013). Mulsa Organik Meningkatkan Hasil dan Mengatasi Kekeringan. Kementrian Indonesia, Jakarta.

[3] Irma, I., Pasigai, M. A., \& Mas'ud, H. (2018). Pertumbuhan Dan Hasil Bawang Merah (Allium Ascalonicum L.) Terhadap Pemberian Berbagai Dosis Pupuk Npk. Agrotekbis: E-Jurnal Ilmu Pertanian, 6(1), 18-26.

[4] Sumarni, N. dan Hidayat A. (2005). Budidaya Bawang Merah. Balai Penelitian Tanaman Sayuran. Jakarta Selatan

[5] Soenyoto, E. (2016). Pengaruh Dosis Pupuk Anorganik Npk Mutiara (16: 16: 16) Dan Pupuk Organik Mashitam Terhadap Pertumbuhan Dan Produksi Tanaman Bawang Merah (Allium ascalonicum L.) Varietas Bangkok Thailand. Jurnal Ilmiah Hijau Cendekia, 1(1), 21-27.

[6] He, Z., Griffin, T. S., \& Honeycutt, C. W. (2004). Evaluation of soil phosphorus transformations by sequential fractionation and phosphatase hydrolysis. Soil Science, 169(7), 515-527.

[7] Lingga,P dan Marsno (2008). Petunjuk Penggunan Pupuk. Bandung Penebar Swadaya

[8] Suhartono. (2012) Unsur-unsur Nitrogen dalam pupuk urea. UPN Veteran. Yogyakarta.

[9] Supriadi, Y. Husna dan S. Yoseva (2017). Pengaruh Pemberian Pupuk Kandang dan Pupuk N, P dan K Terhadap Pertumbuhan dan Produksi Tanaman Bawang Merah (Aliumcepafa ascalonicum L.). JOM FAPERTA 3(2): 1-13. (2017)

[10] Setiyowati, S.H dan R.B. Hastuti (2012). Pengaruh Perbedaan Konsentrasi Pupuk Organik cair 